\title{
Local Genius of Engganese Community in Bengkulu Province (An Etnographic Study of Health and Illness Perception)
}

\author{
Daisy Novira* Idramsyah \\ Nursing Department of Health Polytechnic The Ministry of Health, Bengkulu
}

\begin{abstract}
The island of Enggano is the outermost small island on the west coast of Sumatra and administratively under the region of North Bengkulu. Limitations on transportation access, health referral services, and resources are problems experienced by people in the island of Enggano.This study aims to explore the local genius of the Engganese community regarding the perception of health and illness. The study used a qualitative method with an ethnographic approach. Data collection has done through observation, in-depth interviews, and documentation studies. Data processing and analyzing used ethnographic analysis through several stages, namely description or domain analysis, compound analysis, interpretation, and research reports development. The research was carried out on the island of Enggano which included several villages of Banjarsari, Meok, Apoho, Malakoni, Kaana, and Kahyapu.The results of the study showed that Enggano cultural elements include religion, language, livelihood, typical food, prevailing social norms and the system of community organizations and Enggano traditional houses; Local community skills can be seen from various dimensions, namely local knowledge, local values, local skills, local resources, decision-making mechanisms and solidarity, and community perceptions of health and illness.
\end{abstract}

Keywords: cultural elements, local genius, perception of health and illness

DOI: $10.7176 /$ RHSS/9-4-05

\section{Introduction}

Bengkulu Province consists of 9 (nine) regions and one municipal city, namely Regencies of Central Bengkulu, North Bengkulu, Kepahyang, Rejang Lebong, Lebong, Muko-Muko, Seluma, South Bengkulu, Kaur, and Bengkulu City. Like other provinces in Indonesia, Bengkulu has diverse cultural elements. Each regency and city in Bengkulu Province have distinctive cultural characteristics including Engganese community on the island of Enggano, an island located in Bengkulu province..

Based on the Presidential Decree No. 6 of 2017, the island of Enggano is designated as one of the outermost small islands in Indonesia located in Bengkulu Province with a distance of 90 nautical miles from the city of Bengkulu. Administratively the island of Enggano is under North Bengkulu Regency. Transportation access to the island of Enggano is still limited by ferryboat of KM. Raja Enggano which comes twice a week and takes 12 hours or by airplane which is often constrained by weather conditions. However, the aircraft transportation contract with Susi Air has expired since December 2017. Therefore aircraft transportation is not available at the current time until the renewal contract with any airline in the future. By airplane, it only takes 45 minutes to reach the island of Enggano.

The tidings from the island of Enggano spread from "mouth to mouth" or through the media which occasionally broadcasts information of the happening activities in the island. Therefore, the very limited information about the community lived on this island is resulting so many Bengkulu people are not aware of the life on the island of Enggano.

Some problems on the island of Enggano have been discussed in several articles, Cahyadinata (2009) showed that $58.1 \%$ of residents on the island of Enggano suffered from food insecurity. Community groups suffering from food insecurity include farmers and fishermen. This condition has the potential to disrupt the health and productivity of the community.

Coastal and Small Islands Study Center of University of Bengkulu in a research discussion forum held by LPPM UNIB on February 9, 2018, revealed other problems found in the island of Enggano including limited resources of both human and other supporting facilities such as the availability of electricity sources. Regardless the existence of PLTD (Diesel Generator) with $20 \mathrm{kV}$ capacity and PLTS (solar Generator) with $2 \mathrm{MW}$ capacity operated by the airport, the community still has to manage the self-funding generator to meet electricity needs. Besides, the motivation and perception of Engganese community towards education are still low due to the lack of supporting infrastructure, economic and nutritional status and low interest in education.

However, there are many natural potentials that can be utilized and developed for the welfare of the community, but they have not been managed properly due to limited resources. Tourism potential that can be developed needs to consider the local wisdom and customary law applied in the community to avoid any conflict in the future.

Another problem according to Chief of Apoho village is the lack of doctors, only one doctor is assigned on the island of Enggano. Ironically, once in the past, a sick Engganese died in his way to get referral treatment to Bengkulu city due to lack of access to transportation and the same happened again last year. He also said to 
Radar Bengkulu Utara Newspaper (February 9th, 2018) that health services at Enggano Mobile Hospital were disrupted because contract medical staff (TKK) and regional medical staff (TKBD) were dismissed. Those staffs are native Engganese and have been working for the community for quite long. Meanwhile, the medical staff and nurses assigned in the hospital only carry out their duties on the island for a few days, and they are mostly stationed in Bengkulu city. The staff used to be away for two or three months before coming back to the island. In line with what was said by the chief of Kaitora clan, the process to transfer a patient from the island of Enggano to Bengkulu city is difficult due to the restrained transportation access. The hospital in Enggano has been neglected since it was signed over to North Bengkulu Regional Government in 2015 with the limited budget for operational funds of only Rp. 300 million from the APBD. Frequently, one medical staff, two nurses and a midwife are not in duty, and the only person in charge in the hospital is merely an administrative officer. Within the last 10 years, 7 (seven) people died because of tardy health treatment.

\section{Method}

This study used a qualitative method with an ethnographic approach. The ethnographic approach emphasizes contextual aspects by eliminating theoretical or hypothetical assumptions to generate the inherent study. The study was conducted on the island of Enggano in October 2018. The researchers departed from the Bengkulu city on October 9, 2018, at 9:00 p.m. and arrived on the island of Enggano on October 10, 2018, at 10:35 p.m. after traveling for 13.5 hours by KM. Pulo Telo ferryboat. The research was carried out in Enggano district consisting of 6 (six) villages of Banjarsari, Meok, Apoho, Malakoni, Kaana, and Kahyapu. Data collection was done in several ways such as observation, in-depth interviews, and documentation studies. Observations and interviews were the main instruments in collecting.

\subsection{Observation}

There are four types of observation, namely complete observer, participant observer, participant as the observer and complete participant. Observations were done with the observer model as a participant. In this case, the researchers observed community activities along the morning until late evening.

\subsection{In-depth Interview}

In-depth interviews were given to informants or research subjects. The informants of this study consisted of main informants and supplementary informants. Main informants were traditional leaders, chiefs of 6 (six) clans of Kaitora, Kauno, Kaarubi, Kaharuba, Kaahaoao, and Kamay. Interviews with supplementary informants involved village chiefs and medical staffs, this was done for data triangulation or compound analysis toward the data obtained from the main informants. In-depth interviews were carried out using interview guidelines, field notes, and video recordings.

Informants' characteristics can be seen in the following table:

Table 1. Informants' Characteristics

\begin{tabular}{|l|l|c|l|l|}
\hline NO & NAME & Age (year) & Sex & \multicolumn{1}{c|}{ Position } \\
\hline 1. & Mr..S & 42 & Male & The Chief of Banjarsari Village \\
\hline 2. & Mr. IK & 45 & Male & The Chief of Meok Village \\
\hline 3. & Mr. RH & 42 & Male & The Chief of Apoho Village \\
\hline 4. & Mr. Ns & 36 & Male & The Chief of Kahyapu Village \\
\hline 5. & Mr.AS & 65 & Male & The Chief of Western Region of Kamay Clan \\
\hline 6. & Mr. Abs & 58 & Male & The Chief of Kauno Clan \\
\hline 7. & Mr. M.RK & 60 & Male & The Chief of Kaitora Clan \\
\hline 8. & Mr. Zl & 84 & Male & The Chief of Kaharuba Clan \\
\hline 9. & Mr. Ab & 89 & Male & The Chief of Kaarubi Clan \\
\hline 10. & Mr. M.Jr & 65 & Male & The Chief of Kaahoao Clan \\
\hline 11. & Mr. Sy & 72 & Male & The Chief of Kamay Clan \\
\hline 12. & Mr. Msk & 70 & Male & Hospital Caretaker \\
\hline 13. & Mr. EJ & 32 & Male & Head of Enggano Health Center \\
\hline
\end{tabular}

Most of the chiefs are High School graduates while some earn bachelor degree such as the chiefs of Apoho and Malakoni villages, chiefs of the Kaahao, the Kaitora and the Kaarubi clans, and chief of the Kamay clan is a police veteran while the Head of Enggano Health center is Diploma III in Nursing.

\subsection{Documentation study}

Documentation study refers to the previous studies published in scientific journals, textbooks and other documents regarding to procedural guideline of Customary Rituals of Engganese community written by Ulayat Bengkulu Foundation in 2003. 


\subsection{Data Analysis}

This study used ethnographic analysis which is inductive based on the participants' perspective. The analysis had been started since the field observation result came out. The analysis is a meaning interpretation analysis into narrative and information or description that can use quantitative data.The researchers used Spradley data analysis model. Descriptive stage of qualitative research emphasizes this study in a form of storytelling where the researcher as the storyteller tells the reader of what was seen and experienced along the study.

The first stage analysis was data collection arrangement into a chronological series. The researchers conducted domain analysis or a general description data collection result which is a general description of the Enggano cultural elements, then applied a compound analysis. The analysis was done by comparing the differences from the results of data collection. At this stage, some information required triangulation validity from other informants or it was also possible to conduct field assessments directly. Some aspects requiring a compound analysis were related to the perception of the illness and its treatment, namely perihei and angin duduk and the information regarding the hospital medical staff whereabouts.

The next stage was sorting the data and displaying the findings in the table such as the characteristics of the informants and the analysis of in-depth interviews results with informants. In this case, the researchers made a recapitulation of the interviews results.

The third stage is the ethnographic interpretation or data transformation. Here, the researchers considered the mismatched data that can lead to miss-interpretations and readers' doubts. Personalization was also done at the stage of interpretation. One unique thing in ethnographic research was that researchers could not really identify what approach to use until they actually start the data analysis process. As the result, the researchers wrote the story based on the analyzed elements into a report as a storyteller.

\section{Result}

\subsection{Cultural Elements of Engganese}

The cultural elements of Engganese community observed in this study were religions, language, livelihood, typical food, prevailing social norms and the system of community organizations and the traditional house of Enggano.

According to the chief of Apoho village, the majority of the religions of Engganese is Christians(75\%) and the rest are Muslims. while in Enggano District the data shows that the Muslim population is $66.54 \%$ and Christian is $33.45 \%$. The harmony of life among the Engganese is obvious despite the different religions and clans including migrants. People live and value the mutual respect, mutual cooperation and help each other especially in celebration or event in the village. Harmony among the Engganese is also fostered by the belief in ancestral spirits and customs that have been the guideline for the community on the island of Enggano.

One good example was in the weddings preparatory in Banjarsari village. All Engganese from various clans and religions worked together to build tents, cooked and other preparations for the party. The village chief of Banjarsari said:

"We prioritize unity despite the difference in religions, if you see on TV, many educated people like professors keep fight each other and spread blasphemy, it's useless, we have always been showing the life of mutual respect towards the differences ."

The language used in everyday life was Indonesian so researchers had no difficulty in interviewing chiefs of clans. The native language of Enggano is still used in two villages, Meok and Apoho, while others use Indonesian to communicate. The concern about the loss of Enggano language was revealed by the Kaahoao chief. He was once offered to teach Enggano language at school, but he eventually rejected because the compensation provided by the government was inadequate.

"There should be teachers to teach Enggano language, I was offered but only got paid 100 thousand rupiahs a month ... it's not enough. The government has not paid attention to the existence of Enggano adat. For example, in a traditional Congress, there is no government support. The public and the government should be able to work together in fostering customs, taking care of it."

The livelihoods of people on the island of Enggano are farmers and fishermen. In average, Engganese has plantations of banana, bagug (Gnetum gnemon), djengkol (Archidendron pauciflorum) and cocoa. In coastal areas, people work as fishermen for fish and lobsters. Lobster is also cultivated in Banjarsari village. Communities in Meok village also open lodge and guess house businesses, food stalls, workshops, and grocery stores. Enggano's biggest revenue comes from kepok banana trading. Kepok production reaches 140 tons per week. Those bananas are loaded into trucks and shipped to Bengkulu by ferryboat. However, oftentimes those bananas cannot be shipped and wasted because of the limited shipping capacity.

Enggano's typical food is smoked sea-turtle and it is served during weddings and ceremonies such as Buka Pantang, the death of clan chiefs or welcoming guests ceremonies. In addition to sea-turtle dishes, there are also leaf-wrapped sweet potatoes and taro. The number of sea-turtle dishes is limited to 5 turtles per serving in each 
ceremony but this rule is often violated. This is still an issue on the island of Enggano. In one side Engganese knows that turtle is the protected animal, but on the other side, Engganese believes that without serving sea-turtle dish in any ceremony or rituals can bring bad luck to the island. The researchers and team have once encountered the preparation of Buka Pantang ritual in Malakoni village, but due to the departure scheduled to Bengkulu and bad weather, the team could not attend the whole ceremony. Buka Pantang ritual is a ceremony to seek permission from the ancestral spirits to hold a party or feast after the death happened in the village.

Social norms that apply on the island of Enggano are customary norms which are still strongly followed by the community. Customary procedures are set forth in Customs and Ceremonies Guidelines of Enggano which contains provisions, sanctions, and forms or types of sanctions for customary law. The guidelines also state the types and forms of traditional ceremonies and the management of them. These guidelines are compiled by clan chiefs on the island of Enggano.

Community on the island of Enggano has lineal kinship based on the origin of descendants called clan. There are 6 ( six) clans on the island of Enggano namely the Kauno, the Kaitora, the Kaahoao, the Kaarubi, the Kaharuba, and the Kamay. Each clan has gate led by deputy chief or gatekeeper. The coordinator of clan chiefs is called Paabuki. The Kamay is the clan for immigrants. Therefore, non-native or migrants on the island of Enggano are classified into this clan and accepted as residents of the island of Enggano.

The origin derivation of 5 clans on the island of Enggano comes from the names of trees and animals with traits inherent in them containing meaningful philosophies for each clan. The Kaahoao comes from the word ahua'y (ko'iyao) or bagug plants (Gnetumgnemon) that grow a lot on the island of Enggano, the trunk is weak but it is not easily broken and all branches produce plentiful edible fruit. The Kauno comes from the word ea'unno which is a type of fish that lives swarming and agile and beneficial to human livelihoods. The Kaitora is derived from the word ittora, a very strong and hard wooden terrace. The Kaarubi is from the word eadubbi, a plant that grows straight stem which is taller than any other plants. The last, the Kaharuba which comes from the word change'hi, which means flexible mind or the nature of open-minded.

Engganese practices the matrilineal system from the maternal lineage. However, in honor to the paternal line, the clan names start with " $\mathrm{K}$ " letter derived from the wordkamanippa.

Besides the clan kinship system, village government affairs are entrusted to village chiefs who lead 6 (six) villages of Banjarsari, Meok, Apoho, Malakoni, Kaana, and Kahyapu.

Enggano traditional house is owned by all clans with a hexagonal shape and rounded roof called yup kakadie. To enter the house, the research team needed to get permission from the Kaitora house guards. The key to the traditional house is held by the Kaitora deputy chief who lives in Meok village. The Kaitora traditional house was made of solid merbau wood. The house is a two-story house. In the basement, there are a wide open space hall and a transversely installed door connecting the first floor. The upstairs consists of two rooms and a balcony. Several household utensils, machetes (pamos) and spears (kaek) are all posted on the balcony wall. There are several types of spears, namely pineapple eye spears, piarit spears and payah fish spears for a war dance. There is also a mortar to pound rice made of aluminum-coated wood.

\subsection{The Dimensions of Local Wisdom}

Community local wisdom can be seen from various dimensions, namely local knowledge, values, skills, resources, decision-making mechanisms, and solidarity.

Local knowledge possessed by the community has a positive impact on the preservation of mangrove forests. Mangrove forests should not be disturbed and anybody who does will be fined. Mangroves are known to protect the coast against the tidal waves. The local values applied in the community is the customary norms that should be obeyed not only by the native Enggano, but the immigrants are also required to respect the local values adopted by the community.

Local skills possessed by the Engganese community are cultivating bananas, bagug, djengkol, cocoa and fishery. Besides, the Engganese men are also adept at making canoes, and women are skillful to make woven from fine rattan into baskets or woven screw-pine mats. Crafts of shellfish ornaments, sea snails bracelets and key chains and bahar root bracelets are also produced by one Engganese lived in Kaana village. Salted fish from Enggano is also one of the commodities. However, due to limited transportation and electricity supply, the utilization of crops and handicrafts is not optimal, especially in the marketing aspect. The village chief of Kahyapu complained:

"We (three villages) have agreed to grant land for the banana cannery, but until now there has been no realization from the local government. Bananas are often rotten and wasted due to limited transportation"

The decision-making mechanism in Engganese community still applies customary law. Clan chiefs actually have a central role in making decisions on every issue, even the chiefs has the right to revoke cases related to the issue of disputes. In addition, the chiefs also determine votes in regional head elections if needed. However, in the present, the role of the chiefs is reduced. This is stated by the chief of Kaahoao clan : 
"Customs were governed by the chiefs of the clan, but now it is reversed. Back there, there was one Enggano cultural performance held by a dance studio from Bengkulu without chief's concern. I was offended because when the dance was performed it was commented as a primitive dance of the Engganese. And when they performed at Taman Mini, three dancers got possessed. I was asked to exorcize them with water, Nipah cigarettes, betel leaf, baked sweet potatoes and prayers in Enggano language. This happened because they had committed a violation."

Local resources on the island of Enggano consist of natural resources of the agricultural, plantation and marine products. Tourism potential that has not been utilized is one potential local resource that can be developed. In addition, Enggano also has human resources with unique local wisdom, the spirit of camaraderie, honesty, and tolerance.

The dimensions of local proficiency, which are obvious among Engganese community, are high social solidarity, acceptance to migrants, mutual respect, cooperation and fostering the value of honesty. Based on the observations, the motorbikes parked in the yard for nights and days with the ignition key still installed would never get stolen. Social control is still preserved with customary law applied to every violation.

\subsection{Perception of Health and Illness}

In general, people's perception of being sick is when a person cannot carry out daily activities as usual. From the traditional point of view, people assume the supernatural beings causes the illness or bad weather makes a person get sick. Therefore, the treatment will be based on people's perceptions of the cause of the illness.

Native Engganese still believes in Perihei. Perihei is a magical power that causes someone sick that is mostly in the state of severe stomache pain after eating which lead to death. They believe that s/he eats without offering some food to the passerby who possesses the perihei inherited from his/her ancestors. If someone suffers from perihei, then it cannot be treated medically, but through magical powers belonged to certain clans. The tribe that has a perihei is the Kaahoao. The Engganese mythology tells when a famine occurred and people had starved to get food the Kaahoao swore an oath in the spirit of Kinen Bay that if a person has food and does not share it with others, he will be cursed.

The therapy given to someone suffered from perihei is by wrapping the patient with a pandanus mat, then the healer takes the heated coconut stem and then sweeps it over the ailing body while reading the prayers or mantra. Usually, the patient is asked of whom $\mathrm{s} /$ he met before when $\mathrm{s} / \mathrm{he}$ ate because the healer had to mention the name the patient met.

The illness caused by a disruption of the balance of natural conditions is angin duduk (angina pectoris). Someone who suffers angin duduk feels severe chest pain spread to the hands and back, the sensation feels like someone is stepping on your chest, hands and sometimes in the stomach, as it was told by the Kauno chief :

"The pain spreads like getting pierced by a needle. There are three kinds of angin duduk, it can paralyze the hands, causes stomach, or it feels like an egg twirling in the stomach, chest, hands, and feet. This must be treated quickly within 24 hours and before patient vomits."

Therapies that are given to the patient with this illness are massage, "revoked" ritual, warm compressed. Then the healer slits a chicken, splits it up, and places it on the patient's chest. According to the chief of Kauno clan, the chicken blood is absorbed dry into the patient's body and chicken meat cooked by the high temperature of the patient's body.

Based on the interviews with the chief of Apoho village, angin duduk is not due to bad weather but due to the voodoo which is deliberately spelled by the enemy and brings illness to the concerned or his family. This is done as revenge to the victim.

The chiefs suggested if someone suffers from perihei or angin duduk patient must seek treatment immediately from the healer with the ability to treat the voodoo instead of seeing the doctor or paramedic.

Herbal therapy is also carried out by the community for common diseases. For example, malaria can be cured with subang-subang leaf, the fruit is white, and it is herb for an eyesore. Subang-subang can be found on the beach but it is rare now. The community also uses soursop leaf for high blood pressure and fever.

The community's expectation towards health services is the availability of doctors and nurses who are available when needed, especially in emergency cases. Such as in the death case of a fish diver due to the broken oxygen hose when he dived at five meters deep. He died due to lack of emergency treatment because the Health Center and hospital were far away to reach. It happened in Kahyapu village, and it took one hour to reach the district center.

Based on information from the head of the Health Center, people on the island of Enggano commonly suffered from ISPA (Acute Respiratory Tract Infection/ARI). The number of medical staffs who is always available at the institution is 29 personnel. The average number of patients per day is 8 (eight). The existence of general practitioners has always been a problem for informants, both the village and clan chiefs. The doctor is never on the island but in Bengkulu and possibly to not return for more than a month. The data of 5 (five) major 
diseases reported by the Enggano Health Center can be seen in the table below :

Tabel 2. The data of 5 (five) major diseases January-September 2018

\begin{tabular}{|c|l|l|l|l|l|}
\hline Month & \multicolumn{1}{|c|}{$\mathbf{1}$} & \multicolumn{1}{|c|}{$\mathbf{2}$} & \multicolumn{1}{c|}{$\mathbf{3}$} & \multicolumn{1}{c|}{$\mathbf{5}$} \\
\hline January & Dermatitis & Gastritis & ARI & $\begin{array}{l}\text { Gout } \\
\text { Arthritis }\end{array}$ & Hypertension \\
\hline February & $\begin{array}{l}\text { Rheumatoid } \\
\text { arthritis }\end{array}$ & Gastritis & ARI & $\begin{array}{l}\text { Gout } \\
\text { Arthritis }\end{array}$ & Cephalgia \\
\hline March & ARI & Gastritis & Dermatitis & Cephalgia & - \\
\hline April & ARI & Dermatitis & Gastritis & Cephalgia & $\begin{array}{l}\text { Rheumatoid } \\
\text { arthritis }\end{array}$ \\
\hline May & ARI & $\begin{array}{l}\text { Rheumatoid } \\
\text { arthritis }\end{array}$ & Cephalgia & Gastritis & Dermatitis \\
\hline June & Dermatitis & ARI & $\begin{array}{l}\text { Rheumatoid } \\
\text { arthritis }\end{array}$ & Gastritis & Dermatitis \\
\hline July & ARI & Cephalgia & Gastritis & Dermatitis & V. laceratum \\
\hline August & ARI & Gastritis & Cephalgia & Dermatitis & - \\
\hline September & Gastritis & Dermatitis & ARI & Cephalgia & Diabetes \\
\hline
\end{tabular}

Source: Enggano Health Center, 2018.

Based on the above data, acute respiratory infections (ARI) are often found in this district. The rain did not fall for three months in Enggano district so that the dust fogged the road and became one of the factors causing a high rate of ARI cases.

\section{Discussion}

\subsection{Cultural Elements}

Universal Cultural elements of Engganese community is visible including religion, language, livelihood, typical food, prevailing social norms and community organization systems.

Researchers did not have difficulty communicating with the chiefs of clans or native Engganese on the island of Enggano because they had mingled with migrants with Indonesian as the everyday language to communicate. Enggano language is only used among fellow native among clans, and it is only spoken in two villages, Meok, and Apoho. Unless there is an effort to preserve the Enggano language, it will slowly disappear and unknown by the young generation.

There is difference information between the data from the district office and the chief of Apoho village regarding the number of religious followers in Enggano. This difference may occur based on different data sources. Districts office conducted the census starting from Banjarsari to Kahyapu villages. While the chief of Apoho village focused on the community of Apoho village and the nearest village, Meok, which is predominantly Christian.

The cultural manifestation can be seen in artifacts of traditional houses and tools used by traditional people. In line with the views of Talcott Parson cited by Koentjaraningrat (2009) culture is associated with elements of action. Culture cannot be separated from the personality of individuals through the learning process. Human ideas, behavior, and actions are organized, controlled and strengthened by various systems of values and norms.

Traditional houses of each clanon the island of Enggano are similar in hexagonal shaped with rounded roofs and a two-story building. The only difference is the Kaitora house was self-funded so that it is more solid than other traditional houses funded by the local government.

\subsection{Dimensions of Local Wisdom}

Guidelines for the customary procedures of the Engganese community become a guideline in the applied value system, regulating social institutions for the survival of the community. Whereas local proficiency or local wisdom known as a local genius in Anthropological terminology has become the spirit of Engganese community to survive against obstacles in this needy life. Limitations include limited transportation access, limited electricity supply which only lasts for 14 hours a day and lack of health services as well as access to communication and information.

The social capital possessed by Engganese community is a kinship and mutual cooperation system, and mutual respect among one another despite the different ethnicity and religions. As the example, the Kamay clan is a mix of several ethnic groups coming from outside of the island of Enggano. They live harmoniously side by side among their own and to other clans of the Island of Enggano. This is in line with the research conducted by Suwitha (2016) that indicated well-maintained collaboration and associative relations among various ethnic groups . 
The community in Banjarsari village worked together to get their own generator to fulfill electricity needs. They also used to carry out mutual cooperation whenever a celebration is held by one of the residents, so the others gladly helped to prepare the celebration.

Besides, the honesty values lie in the community can be seen from the security situation on Enggano Island. Although there are not law enforcement officials on the island, no one gets stolen or robbed. Two-wheeled vehicles parked on the yard even with the ignition key, remain safely until the next days.

The uniqueness of flora and fauna varieties in the island is because Enggano is an oceanic island which has no geological string to the island of Sumatra. Enggano local resources are one of the dimensions of the local genius. In line with the results of the LIPI research (2015), it is stated that the natural wealth and tourism potential of Enggano is quite good for regional development and advancing the community.

The Engganese community has local knowledge in maintaining mangrove forests in the matter of environmental sustainability but contradictory to the provision of sea-turtle traditional food which sometimes exceeds the allowable amount. The mystic belief is still quite strong in term of the fear of disaster or bad luck if the sea-turtle dish is not served in traditional ceremonial offerings. In this regard, the results of Budiyanto's study (2016) can be a reference on how to apply the functionalization model of local wisdom values in regional legal policies in the aspect of natural resource management and environmental preservation.

\subsection{Perception of Health and Illness}

The limited resources experienced by Engganese community are created upon the lack attention of the local government towards the existence of the Engganese clans and the provision of infrastructure needs, and the fulfillment of standard health services for the community. The absence of doctors had long been complained, but there have never been follow-ups to resolve the problem. Hospitals are often left empty during working hours, even doctors assigned by local government are frequently away and do not return on duty for more than a month. If health services are inadequate, the Engganese community will be more adamantto believe their concepts of health and illness according to their traditional views.

Individual cultural perception is in accordance with the cultural perceptions held by the community including the concept of being healthy and sick. This understanding affects their behavior in maintaining their health. Besides capable to receive medical treatment for certain diseases, the Engganese also still believes and are influenced by traditional views relating to the causes of the illness and ways to treat it. In line with Jimung's view (2017) that healthy behavior influences their way of maintaining health, and sick behavior is an action taken by the community to seek treatment.

There was something different about the concept of the illness according to the Kauno chief and his method of treatment. The chief of Kauno clan believed that the cause angin duduk is naturalistic of weather imbalance, but the treatment intervention was based on the personalistic view. The Apoho village chief was in line with the ethnomedical view of the concept of the personalistic illness causes. Angin duduk was caused by voodoo (personalistic) so that the therapy is also based on personalistic perception rather than herbal therapy (naturalistic).

\section{Conclusion}

Based on the results of the study it can be concluded as follows:

a. Enggano cultural elements include religion, language, livelihood, typical food, prevailing social norms, community organization systems, cultural artifacts in the form of Enggano traditional houses, along with tools and equipment in them.

b. Local skills are examined from several dimensions, namely local knowledge, local values, local skills, local resources, decision-making mechanisms, and solidarity.

c. Traditional community perceptions of health and illness from the ethnomedical aspect are personalistic and naturalistic causes so that the treatment or therapy depends on people's perceptions of the cause of the illness.

Suggestions for improvement and development of the island of Enggano are as follows:

a. It needs attention from local government regarding the existence of the culture and customs of the Engganese community and it should be equal with that received by other tribes in Bengkulu Province.

b. Local government needs to evaluate the existence of Enggano mobile hospitals regarding the absence of doctors and other medical staff, so that community will not experience any obstacle for health services in hospitals.

c. The fulfillment of transportation access, the availability of electricity, access to communication and information so that local potential can be utilized maximally. 


\section{References}

Adhi,Made Kerta. (2016). The Strategy of Cultural Poverty Alleviation Based on Empowering Local Genius. International Journal of Science and Research (IJSR) vol5, issue11.November 2016.p.1569-1573.

Barker,Chris. (2009). Cultural Studies Teori dan Praktik (terj). Bantul : Kreasi Wacana.

Basri, Laode Ali. (2011). Local Genius As Socio-cultural Capital for Empowering the Bajo Ethnic People Residing at the Coastal Area of Bungin Permai Village, South East Sulawesi. E- Journal of Cultural Studies [Vol.5,1 Jan 2011; date accessed: 5 Dec. 2017] Retrieved from https://ojs.unud.ac.id/index.php/ecs/article/view/3631

Cahyadinata, Indra. (2009). Kajian Ketahanan Pangan Masyarakat Pesisir Pulau Enggano dan Efeknya Terhadap Kesejahteraan : Pijakan Strategis Pembangunan Pulau Kecil Terluar. Laporan Penelitian Hibah Penelitian Strategis Nasional. Bengkulu : Fakultas Pertanian Universitas Bengkulu.

Creswell, John W. (2007). Qualitative Inquiry and Research Design Choosing Among Five Approaches. USA : Sage Publication

Creswell, John W. (2008). Educational Research : Planning, Conducting and Evaluating Quantitative and Qualitative Research. New Jersey : Prentice Hall

Ekorusyono. (2015). Mengenal Budaya Enggano. Cetakan ketiga. Yogyakarta : Buku Litera

Ekorusyono. (2017).Pendekatan Folklore dalam Menganalisis Nyanyian Rakyat "Kahinoa" Masyarakat Enggano. [7 August 2016, cited 27 Nov 2017] Retrieved fromhttp://diobagitetunjang.blogspot.co.id/2016/08/folkloreenggano.html

Hanifah,Ninip. (2010). Penelitian Etnografi dan Penelitian Grounded Theory. Jakarta : Akademi Bahasa Asing Borobudur.

Irmayani,Tengku, Nurbani,Bangun,Sabariah.The Synergy of Local Genius in the Development Policy Strategy South Nias Regency. International Journal of Management Science and Business Administration. Vol.3(6).p.28-37 [September,2017.cited $18 \quad$ Feb 2018$] \quad$ Retrieved from http://dx.doi.org/10.18775/ijmsba.1849-5664-5419.2014.36.1004

Jenks,Chris. (2013). Culture Studi Kebudayaan (translation). Yogyakarta: Penerbit Pustaka Pelajar.

Jimung,Martinus.(2017). Antropologi Kesehatan Konsep dan Aplikasi. Jakarta : Trans Info Media.

Keputusan Presiden nomor 6 tahun 2017 tentang Penetapan Pulau-pulau Kecil Terluar.

Koentjaraningrat. (2009). Pengantar Ilmu Antropologi. Cetakan 9. Jakarta : Rineka Cipta.

Narottama,Nararya, Suarja I Ketut, Lestari Denok. (2017). Tumpek Wariga as an Ecology Based Local Genius in Supporting Sustainable Tourism (Case Study of Plaga Village, Badung Bali). International Journal of Applied Science in Tourism and Events. Vol no.1.p.49-61.June 2107

Pangeran, Paita Yunus. (2012). Unsur-unsur kemahiran lokal (local genius) dalam ragam hias Bugis: kajian ragam hias pada rumah tradisional Bugis Sulawesi Selatan dalam unsur-unsur estetika bentuk. Artikel. [Last update 16 Nov 2016, cited 27 Nov 2017]. Retrieved from https://repository.unikom.ac.id/id/eprint/2754

Quinlan,Marsha. (2011). Ethnomedicine. In: Singer,Merril, Erickson, Pamela.editors.Chapter 9. A Companion to Medical Anthropology. UK: Willey Blackwell.

Riadi,Muchlisin.(2017). Pengertian,Fungsi dan Dimensi Kearifan Lokal. Artikel [17 Sept 2017 cited 15bFeb 2018] Retrieved from www.kajianpustaka.com/2017/09/pengertian-fungsi-dimensi-kearifan-lokal.html

Ruastiti,Ni Made. (2011). The Concept of Local Genius in Balinese Performing Arts. Mudra. Vol 26.no.3.p.241245. Dec 2011.

Siregar,Parpen.(2010). Pengelolaan Wilayah Pesisir dan Laut Pulau Enggano Secara Terpadu dan Berkelanjutan. Artikel.[cited 9 Jan 2018] Retrieved from https://uwityangyono.files.wordpress.com/2010/09/psl-pesisirii.doc

Spradley,James.P. (2007). Metode Etnografi (translation). Yogyakarta : Tiara Wacana.

Sudarma,Momon. 2008. Sosiologi Untuk Kesehatan. Jakarta: Penerbit Salemba Medika.

Suwitha,I.Putu Gde. (2016). Local Genius in the Rural Area of Bali: From "Menyama-Braya" to Multiculturalism. International Journal of Linguistics, Language and Culture (IJLCC).vol.2.no.2,p.68-76. July 2016.

Sutarto. (2014). Kearifan Budaya Lokal dalam Penguatan Tradisi Malemang di tengah Masyarakat Modernisasi di Sungai Keruh Musi Banyuasin Sumatera Selatan. [cited 15 Des 2017. Retrieved from http://download.portalgaruda.org/article.php?article=446580\&val=9441\&title=KEARIFAN\%20BUDAYA 20\%20LOKAL\%20DALAM\%20PENGUTAN\%20TRADISI\%20MALEMANG\%20DI\%20TENGAH\%20 MASYARAKAT\%20MODERNISASI\%20DI\%20SUNGAI\%20KERUH\%20MUSI\%20BANYUASIN\%2 OSUMATERA\%20SELATAN

Yunus, Rasyid. (2014). Nilai-nilai Kearifan Lokal (Local Genius) Sebagai Penguat Karakter Bangsa. Studi Empiris Tentang Huyula. Yogyakarta : Deepublish. 